\title{
EFFECT OF PERFORMANCE ASSESSMENT ON EMPLOYEE MOTIVATION IN HOTEL X BANDUNG
}

\author{
Agung Gita Subakti \\ Hotel Management Department, Faculty of Economic and Business, Bina Nusantara University, \\ Jln. K.H. Syahdan No. 9, Palmerah, Jakarta Barat 11480
}

\begin{abstract}
The success of an organization comes from the ability of employees to meet performance standards that have been made by the management of operational activities to be running well. Therefore, knowing how well the employee's performance is a must for the management. A tool used to determine how well the employee's performance is by conducting a performance appraisal. The performance evaluation is one tool used by hotels or other business types to evaluate the performance of employees and also as a tool to motivate the employee. With a good performance assessment will produce a form of accurate data regarding the advantages and disadvantages of the employees and also will motivate employees to perform their tasks
\end{abstract}

Keywords: motivation, performance, assessment, employee, hotel

\begin{abstract}
ABSTRAK
Keberhasilan sebuah organisasi berasal dari kemampuan karyawan untuk memenuhi dengan baik standar kinerja yang telah dirancang oleh manajemen kegiatan operasional. Oleh karena itu, mengetahui seberapa baik kinerja karyawan adalah suatu keharusan bagi manajemen. Sebuah alat yang digunakan untuk menentukan seberapa baik kinerja karyawan adalah dengan melakukan penilaian kinerja. Evaluasi kinerja adalah salah satu alat yang digunakan oleh hotel atau jenis usaha lain untuk mengevaluasi kinerja karyawan dan juga sebagai alat untuk memotivasi karyawan. Dengan penilaian kinerja yang baik akan menghasilkan suatu bentuk data yang akurat mengenai keuntungan dan kerugian dari karyawan dan juga akan memotivasi karyawan untuk melakukan tugas mereka
\end{abstract}

Kata kunci: motivasi, kinerja, penilaian, pegawai, hotel 


\section{INTRODUCTION}

The tourism industry in Indonesia is growing rapidly along with economic growth and utilization the potential of natural and cultural wealth owned. It plays an important role for development as one of the largest sources for the country. Development in various sectors is done not only to improve and promote the economic stability of Indonesia but also as a way to compete with the era of globalization, especially competition with all countries in Southeast Asia. In tourism activities, facilities and infrastructure needed to support tourism activities. The facilities and infrastructure that can support tourism activities are hotels, travel agents, restaurants, recreational facilities and so forth. Of all the means of supporting the activities of tourism, hotels have an important role, where hospitality facilities provide lodging, eating, drinking and other supporting facilities.

Hotel X is one of the three-star Hotel located in Bandung. It provides services that are offered to guests and must be recognized by the guest hotel itself, the rate should be competitive or cheaper, locations that meet the requirements (in the right place), and various other facilities which are the terms of a good hotel. (S Medlik, 2000) state that "A hotel as an establishment providing for reward accommodation, food and drink, for travelers and temporary residents and are usually also meals and refreshment and sometimes other facilities for other user". Of course there are other things to consider in winning the competition, namely human resources or the friendly service, place or building an exciting and fast process, everything that should be seen as a way to generate profits.

In efforts to achieve the objectives, it would be more efficient through cooperation and not by individual who are working alone. Similar to an organization, the hotel also has an employee as implementers, and each individual has a different behavior. A hotel requires an understanding of how to organize and organizational behavior, "An organization is a structured social system consisting of groups and individuals working together to meet some agreed-on objectives” (Jerald Greenberg, 2007) because the understanding of organizational behavior that we can know about how to behave in the organization of individual behavior and its influence on the organization.

Many things can affect the way individuals behave in organizations, one is motivation. "Motivation is hypothetical construct that is used to help explain behaviour" (Luthan, 2002) With motivation, our employees can direct the behavior to be working in accordance with the wishes of organization, "Motivation is a process that starts with a physiological deficiency or need that activates a behavior or a drive that is aimed at a goal or incentive" (Luthan, 2002) in this case relates to how individuals behave. In an organization certainly expect some form of higher performance from their employees, this will be obtained from employees who have high work motivation, it means is that humans who are motivated will work harder, while humans who are not motivated will not work harder if compared. Based on preliminary interviews conducted with the Hotel X, frequent complaints comes from the guests who stay overnight, most of the guests complained about the services provided by the employees.

The results of companies engaged in services are services provided to customers. This service forms can be said to succeed if the customer feels satisfied with the services provided. Therefore, it has a very important role in carrying out those tasks. The management of Hotel X needs to manage its human resources, taking into factors that are affecting the employee's motivation. One of them is the presence of the employee performance appraisal. Assessment of performance is a benchmark for how well the employee's performance compared with existing performance standards.

The performance assessment will produce accurate information about the behavior and

performance of employees, so the management can determine a plan to improve the deterioration found by the assessor and will encourage the good things that have been done by employees. A good 
performance appraisal must be in accordance with and to some of the following guidelines. First, performance ratings must be job-related, with performance standards developed through job analysis. Second, employee must be given a written copy of their job standards in advance of appraisals. Third, managers who conduct the appraisal must be able to observe the behavior they are rating. This implies having a measureable standard with which to compare employee behavior. Fourth, supervisors should be trained to use the appraisal form correctly. They should be instructed in how to apply appraisal standards when making judgments. Fifth, appraisal should be discussed openly with employees and counseling or corrective guidance offered to help poor performance improve their performance. Sixth, an appeals procedure should be established to enable employees to express disagreement with the appraisal (George W. Bohlander, 2001)

Implementation of performance assessment is less well perceived, and therefore contributes to employee motivation, especially at the waiter. Where the management does not involve its employees in performance appraisal process, the assessment was conducted during the one-sided assessment. With no involvement of employees in the assessment, management does not know the needs of the employees, their aspiration that is not met will influence the work motivation. In this article, the author will use the delay of the employee as an indicator in researching about their work motivation. Employee-level data contained the lateness can be seen in the data are at the following chart.

Chart 1 The Lateness of Employee
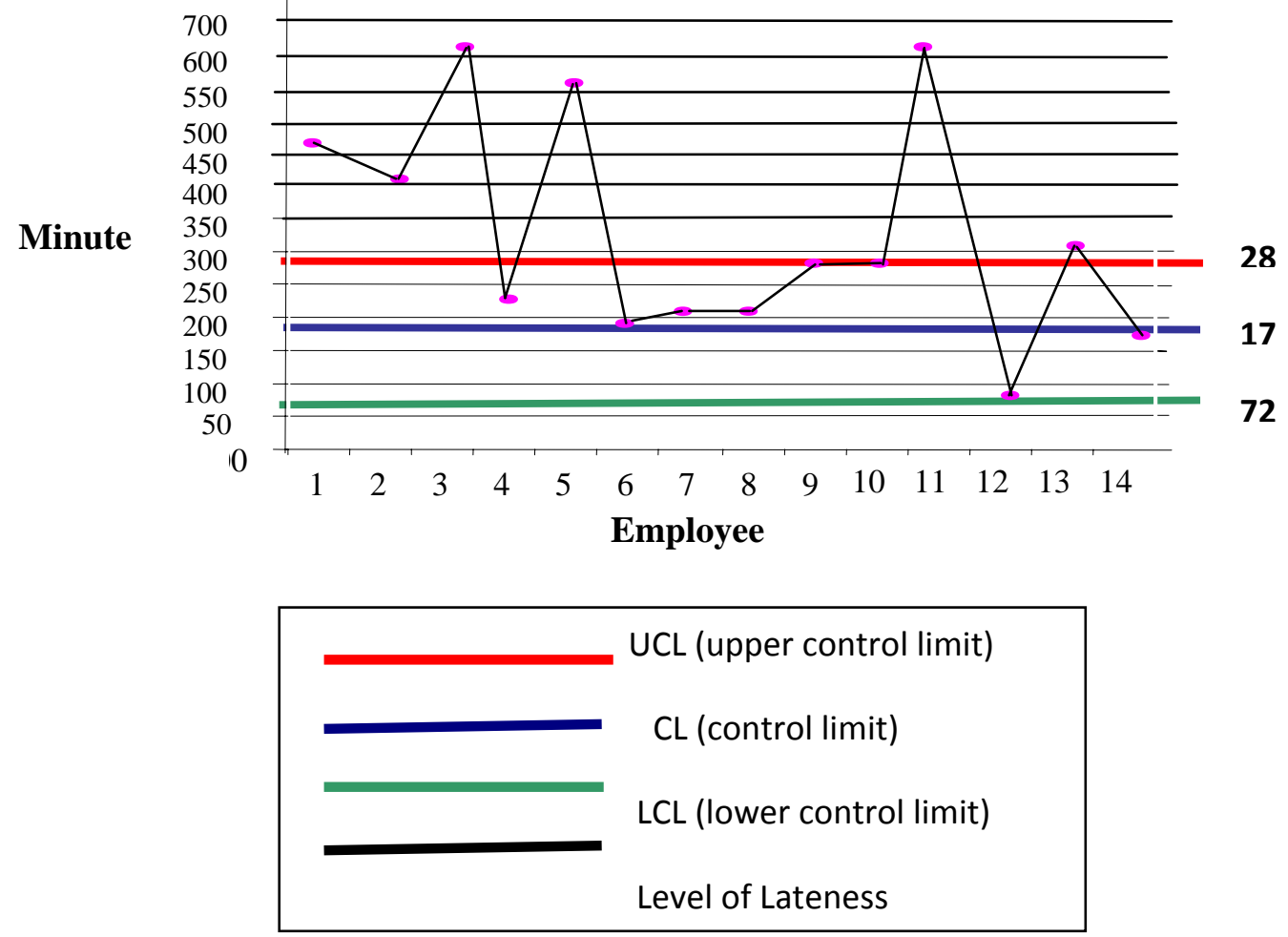

Data above is the number of employee experiencing lateness in a matter of minutes, as for the red line represents an upper limit or UCL and the green line marks the threshold below or LCL from normal limit of delay level. Based on these data we can see that the points above the level of employee lateness in minutes. Late means the employee has violated the rules that have been defined by the management of Hotel $\mathrm{X}$, which are associated with employee's motivation, and then there are several factors that influence the motivation of the research work related to performance assessment. 


\section{RESEARCH METHODS}

The research method used is associative method to seek a relationship between variables and other variables which in this case a relationship between performance and motivation. Data collection techniques, used are stated below. First, interview, is one form of communication performed by two people or more. In doing some researches, interviews have been done either directly or indirectly. In this case, an interview to the Food and Beverage Managers, supervisors, waiters, and the human resource for data.

Table 1 Number of Employees Food and Beverage Department

\begin{tabular}{clc}
\hline No. & \multicolumn{1}{c}{ Position } & Amount \\
\hline 1. & Restaurant Manager & 1 \\
\hline 2. & Head Waiter & 1 \\
\hline 3. & Captain & 2 \\
\hline 4. & Bartender & 2 \\
\hline 5. & Waiter/ress & 12 \\
\hline 6. & Busboy & 3 \\
\hline 7. & Dishwasher & 3 \\
\hline Total & & $\mathbf{2 4}$ \\
\hline Source: Human Resource Hotel X, 2004
\end{tabular}

There are 12 waiters and waitress observed with age between 21-25 years where the lowest education held by employees of such division is a graduate of D1, and most others are D3 Hospitality with average of one year working experience.

Second, Questionnaires, is a research tool by providing a number of written questions. Questionnaire to be distributed and filled out by the Food and Beverage Managers, supervisors, and the waiters. To be able to know the relationship between the two variables, a calculation of Spearman Rank correlation methods has been used. In this method, each response data from employee performance was made into the form of ranking based on respondents' number. The formula of Spearman Rank method is as follows:

$$
\rho=1-\frac{6 \sum b_{1}^{2}}{n\left(n^{2}-1\right)}
$$

The results of the calculation of the correlation will be adapted into form of guidelines to be able to give an interpretation of how strong the relationship of variables that had been counted. Guidelines regarding the interpretation of correlation coefficients can be seen as below: 
Table 2 Guidelines for Interpretation Correlation Coefficient

\begin{tabular}{cccc}
\hline \multicolumn{3}{r}{ Coefficient Interval } & Level of Correlation \\
\hline 0,00 & - & 0,199 & Very Poor \\
0,20 & - & 0,399 & Poor \\
0,40 & - & 0,599 & Adequate \\
0,60 & - & 0,799 & Good \\
0,80 & - & 1,000 & Very Good \\
\hline
\end{tabular}

Source: (Sugiyono, 2010)

\section{RESULTS AND DISCUSSION}

Employee responses to performance assessment of existing mechanisms at the Hotel X should be known and analyzed, because the performance appraisal conducted involving the interests of many people, both the interests of the management and waiters as the object of an assessment.

\section{Analysis on Performance Assessment of Employees at Hotel X}

The first three questions are about the expectancy (Understanding the performance appraisal system, Understanding performance appraisal purposes, and Understanding performance appraisal criteria) of the waiters to the existing performance evaluation mechanism. Assume that for the first three questions have the highest total percentage of 180 by $100 \%$ and the total value of the responses to the implementation of performance appraisal waiter in terms of expectancy is worth 90 or 50\%. From these figures it can be seen that only half of the total value of the highest total, which means an interest or connection with valence on the final result may be associated with this activity is still relatively less.

The next three questions are about instrumentality, (Feedback given, Follow-up of the company after the assessment, the assessment results with the desired expectations of employees). Assume that for these questions has the highest total percentage of 180 by $100 \%$. And the total value of the responses to the implementation has a total value of Instrumentality question 87 or $48 \%$. From these figures, the category of Instrumentality only reaches almost half of the total scores, where relationships of trust between activity / activities with the end result can be considered less.

The last category question is about the valance. In this category, four questions have been made (Opportunity assessment results, Employee involvement in performance appraisal process, Effect assessment of the implementation of work, Effect of assessment in creating career development opportunities). Assume that for the fourth question have the highest total percentage of 240 by $100 \%$ and the total value of the responses to the implementation of performance appraisal for category valance question worth 118 or $49 \%$. From these figures it can be said that the concept of a third offensive individual beliefs about the relationship between business / individual efforts with the tasks to be completed only reached one quarter, this can be considered less.

While the total value of the three categories of employee responses to the implementation of performance assessment is 297 or $49.5 \%$. Overall results from the questionnaire answers regarding waitress responses to performance assessment of existing mechanisms at the Hotel $\mathrm{X}$ in accordance with the Likert Scale is a scale model as below:

In accordance with a scale model of Likert Scale, the highest total score (very good) is $10 \times 5 \times 12=600$, and the lowest score (very poor) is $10 \times 1 \times 12=120$. So, based on the data above, the range between the categories are as follows: 


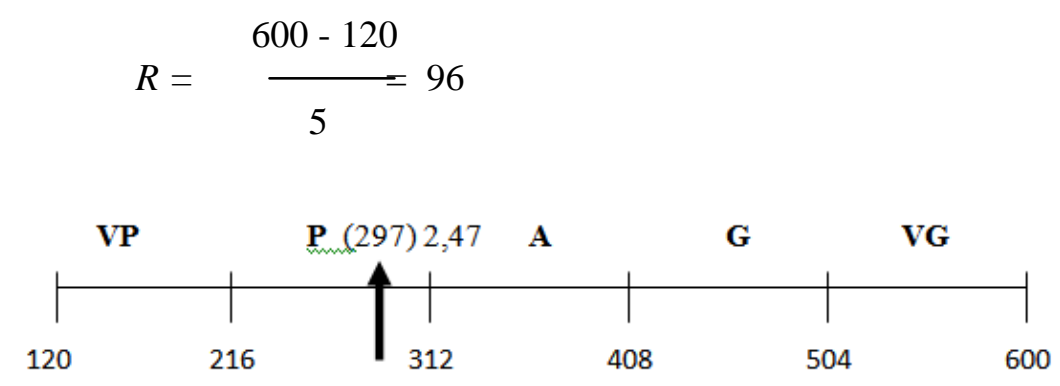

From the explanation above, it can be seen the response of the waiter to unfavorable performance evaluation mechanism. As this can be seen on the scale above which the results of responses to performance evaluation mechanism at the Hotel $\mathrm{X}$ still less than adequate. From the analysis above can be seen that performance evaluation mechanism should be improved for the next period. A good performance appraisal should not be intended only for the interests of the management course, the waiter and waitress as the object of performance appraisal must be involved, so they can know their strengths and weaknesses.

\section{Analysis on Motivation of Employees at Hotel X}

Performance appraisals made into nine numbers (Knowledge of job, quality of work, Ability of work, Job attitude, Cooperation and team work, Work discipline, Initiative, Dependability, Guest Relation) where nothing is considered very good, good valuation 14 times with a total value of 56 or $10 \%$, quite as much as 41 times the assessment with a total value of 123 or $23 \%$, less valuation is 36 times the total value 58 or $11 \%$, the assessment is very less as many as 16 with a total value of 16 or $3 \%$ and the total value of the work performance of employees is 265 or $49.07 \%$.

In accordance with a scale model of Likert Scale, the highest total score (very good) is 9x5x12 $=540$ and the lowest score (very poor) is $9 \times 1 \times 14=108$. so based on the data above, the range between categories are as follows:

$$
R=\frac{540-108}{5}=86.4
$$

Then the performance assessment on employee of Hotel X is 265: $540=49.07 \%$ of the ideal criteria. Score was $49.07 \%$ x $5=2: 45$. Translation of the above can be made scale of the following categories:

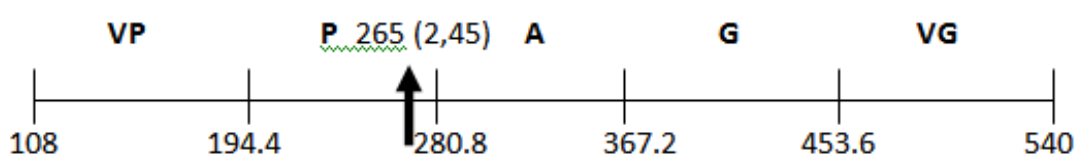

Based on the above analysis, the result of performance assessment on employee of Hotel X still not good enough, viewed from the above position of performance assessment category waiter is still less than adequate. While the management expects the position of work motivation in the position of $70 \%$ to $80 \%$, which is considered as good. 


\section{Analysis on Effect of Performance Assessment on Employees' Motivation in Hotel X}

Collect data group based on performance appraisal as a waitress response variable $\mathrm{Y}$ bound to be variable and performance assessment on employee of Hotel $\mathrm{X}$ as the independent variable as the variable $X$. then the total score from each respondent on each variable can then be known to the research for their respective ratings of the study variables.

Table 3 Score Assessment Questionnaire for Variable Y

\begin{tabular}{ccccccccccc}
\hline $\begin{array}{c}\text { Number of } \\
\text { Respondent }\end{array}$ & \multicolumn{8}{c}{ Questionnaires Answers for number } & \multirow{2}{*}{$\begin{array}{c}\text { Total } \\
\text { Score }\end{array}$} \\
\cline { 2 - 9 } & $\mathbf{1}$ & $\mathbf{2}$ & $\mathbf{3}$ & $\mathbf{4}$ & $\mathbf{5}$ & $\mathbf{6}$ & $\mathbf{7}$ & $\mathbf{8}$ & $\mathbf{9}$ & \\
\hline 1 & 3 & 2 & 2 & 1 & 2 & 2 & 1 & 2 & 3 & 18 \\
\hline 2 & 3 & 2 & 1 & 2 & 2 & 1 & 2 & 3 & 3 & 19 \\
\hline 3 & 4 & 3 & 3 & 3 & 3 & 3 & 4 & 3 & 4 & 30 \\
\hline 4 & 2 & 1 & 2 & 2 & 1 & 1 & 2 & 1 & 2 & 14 \\
\hline 5 & 4 & 3 & 3 & 4 & 3 & 3 & 3 & 4 & 4 & 31 \\
\hline 6 & 3 & 3 & 3 & 3 & 2 & 2 & 3 & 3 & 2 & 24 \\
\hline 7 & 3 & 2 & 1 & 2 & 2 & 2 & 1 & 2 & 2 & 17 \\
\hline 8 & 2 & 1 & 2 & 2 & 1 & 1 & 2 & 3 & 3 & 17 \\
\hline 9 & 4 & 3 & 3 & 3 & 3 & 3 & 4 & 3 & 4 & 30 \\
\hline 10 & 3 & 3 & 2 & 3 & 2 & 2 & 1 & 2 & 3 & 21 \\
\hline 11 & 3 & 2 & 2 & 3 & 2 & 2 & 1 & 2 & 3 & 20 \\
\hline 12 & 3 & 2 & 3 & 3 & 2 & 2 & 3 & 3 & 3 & 24 \\
\hline
\end{tabular}

Table 4 Score Assessment Questionnaire for Variable X

\begin{tabular}{|c|c|c|c|c|c|c|c|c|c|c|c|}
\hline \multirow{2}{*}{$\begin{array}{l}\text { Number of } \\
\text { Respondent }\end{array}$} & \multicolumn{10}{|c|}{ Questionnaires Answers for number } & \multirow{2}{*}{$\begin{array}{l}\text { Total } \\
\text { Score }\end{array}$} \\
\hline & 1 & 2 & 3 & 4 & 5 & 6 & 7 & 8 & 9 & 10 & \\
\hline 1 & 2 & 3 & 3 & 2 & 2 & 4 & 2 & 2 & 3 & 2 & 25 \\
\hline 2 & 3 & 3 & 2 & 2 & 2 & 1 & 2 & 2 & 2 & 1 & 20 \\
\hline 3 & 4 & 3 & 4 & 3 & 4 & 3 & 3 & 4 & 3 & 1 & 32 \\
\hline 4 & 2 & 2 & 3 & 2 & 1 & 2 & 2 & 3 & 2 & 4 & 23 \\
\hline 5 & 4 & 4 & 3 & 2 & 3 & 1 & 3 & 3 & 4 & 3 & 30 \\
\hline 6 & 3 & 3 & 3 & 3 & 2 & 3 & 3 & 2 & 2 & 2 & 26 \\
\hline 7 & 3 & 2 & 3 & 2 & 1 & 2 & 1 & 2 & 4 & 2 & 22 \\
\hline 8 & 3 & 2 & 4 & 3 & 2 & 2 & 1 & 2 & 2 & 1 & 22 \\
\hline 9 & 4 & 3 & 2 & 1 & 3 & 4 & 3 & 3 & 2 & 3 & 28 \\
\hline 10 & 2 & 2 & 3 & 2 & 1 & 3 & 2 & 2 & 3 & 2 & 22 \\
\hline 11 & 3 & 2 & 2 & 2 & 2 & 1 & 2 & 4 & 3 & 3 & 24 \\
\hline 12 & 2 & 2 & 3 & 2 & 1 & 2 & 2 & 3 & 3 & 3 & 23 \\
\hline
\end{tabular}

Source: Results of Processed Questionnaires, 2004

After knowing the score of each respondent on each variable of the study, then we will look for each rank of each research variable, hence the translation of the above we input into a helper table to calculate the Spearman rank correlation as below: 
Table 5 Calculating Spearman Rank Correlation

\begin{tabular}{ccccccc}
\hline No. & $\mathbf{X}$ & $\begin{array}{c}\text { Rank } \\
(\mathbf{x})\end{array}$ & $\mathbf{Y}$ & $\begin{array}{c}\text { Rank } \\
(\mathbf{y})\end{array}$ & $\mathbf{b}_{\mathbf{1}}$ & $\mathbf{b}_{\mathbf{1}}{ }^{2}$ \\
\hline 1. & 25 & 5 & 18 & 3 & 2 & 4 \\
2. & 20 & 1 & 19 & 4 & -3 & 9 \\
3. & 32 & 9 & 30 & 8.5 & 0.5 & 0.25 \\
4. & 23 & 2.5 & 14 & 1 & 2.5 & 6.25 \\
5. & 30 & 8 & 31 & 9 & -1 & 1 \\
6. & 26 & 6 & 24 & 7.5 & -1.5 & 2.25 \\
7. & 22 & 2.3 & 17 & 2.5 & -0.2 & 0.04 \\
8. & 22 & 2.3 & 17 & 2.5 & -0.2 & 0.04 \\
9. & 28 & 7 & 30 & 8.5 & -1.5 & 2.25 \\
10. & 22 & 2.3 & 21 & 6 & -3.7 & 13.69 \\
11. & 24 & 4 & 20 & 5 & -1 & 1 \\
12. & 23 & 3.5 & 24 & 7.5 & -4 & 16
\end{tabular}

\begin{tabular}{lll}
\hline Total & -11.1 & 55.77
\end{tabular}

$$
\begin{aligned}
& \rho=1-\frac{6 \sum b_{1}{ }^{2}}{n\left(n^{2}-1\right)} \\
& \rho=1-\frac{6 \times 55.77^{2}}{12\left(12^{2}-1\right)} \\
& \rho=1-\frac{334.62}{1440} \\
& \rho=1-0.232 \\
& \rho=0.768
\end{aligned}
$$

and correlation dimension are:

$$
\rho=0.589
$$

Information: $\rho$ is Spearman Rank correlation; $n$ is the number of item, and $\mathrm{b}$ is differentiation. Furthermore, the results of the calculation of correlation value will be adjusted with the value contained in the guidelines to provide a useful interpretation of the correlation coefficient to determine the level of relationship variables was calculated. Based on the results of the above, it is mentioned that the two research variables have an adequate relationship.

\section{CONCLUSION}

Based on data and analysis, it concludes several things about the themes adopted. For the purposes of management and employees of hotels, once a year performance appraisal is being held. Basically this is carried out to compare the work of employees within a specific period of work with existing standards. This activity will be beneficial to both parties, whereby the management will 
find accurate data about the performance of the employee and the employee will know their strengths and weaknesses that will be useful for the development of their career future. However, this is not running well, because the implementation of performance appraisal is intended only for management purposes only. With no mechanism for implementation of good assessment, the employees feel that the assessment has been done so far there is no benefit for their future careers.

There are several things in the assessment of the expected performance of employees that need to be fulfilled by the management are:

Create a flow execution of activity of performance appraisal. This strand should include what things should be carried out before and after the performance appraisal. With the existence of this strand, appraisers and employees can find out what their rights and obligations as an appraiser and the object being assessed.

Flow implementations of performance assessment are as follow. First, create a job description, as this as a foundation in the manufacture of performance appraisal format. Second, in creating a performance appraisal format, it would be better if the subordinate is included in determining the assessment criteria, with the inclusion of subordinates, the management will know what will incriminate the employees and make it difficult for its employees, it would be better if all the policies made by the parties involved management subordinates. Third, HRD will determine when the assessment was conducted, assessments should be performed at least once a year. Fourth, supervisors who conduct performance appraisals. In assessing the performance of employees, supervisors should understand about the ways the assessment, having knowledge about the criteria to be assessed so that the assessment in accordance with the facts, objective, fair, honest, responsible and must have data about employees who will be judged (data which can be referred to absenteeism). Moreover, the assessment should be conducted with the assessment format measureable, observable and in each related questions. Fifth, results of performance assessment should be communicated by the employee as a valued object, so that employees can find out how well they have performed the show, and as performance feedback. There will be two results from these activities, the first employee will receive the results given that both supervisors and employees will not receive a positive evaluation results. If employees feel that the appraisal does not match the performance he has displayed for a certain period, he has the right to file an objection, and will be discussed again with the supervisor regarding the results. And if employees receive a positive evaluation results, they will sign the results that have been made by a supervisor. Results from the implementation of performance assessment will produce a good performance feedback as well.

\section{REFERENCES}

Bohlander, G.W. (2001). Managing human resources, $12^{\text {th }}$ ed., South Western College.

Greenberg, J. (2007). Behaviour in organization, $9^{\text {th }}$ ed., Pearson.

Luthan, F. (2002). Organizational behaviour, McGraw-Hill.

Medlik, S. (2000). The business of hotel, $4^{\text {th }}$ ed., Butterworth - Heinemann.

Sugiyono, P.D. (2010). Qualitative and quantitative research method, Bandung: Alfabeta. 